\title{
IMPLEMENTASI PENDIDIKAN KARAKTER PEDULI SOSIAL PADA MASYARAKAT PLURALIS DI CIGUGUR KUNINGAN
}

\author{
Novi Setiawatri dan Aceng Kosasih \\ Universitas Pendidikan Indonesia \\ Email: novisetiawatri@upi.edu
}

\begin{abstract}
Abstrak: Penelitian ini bertujuan untuk mendeskripsikan implementasi pendidikan karakter peduli sosial di masyarakat. Penelitian ini merupakan penelitian kualitatif dengan menggunakan metode deskriptif analitis yang mengambil setting masyarakat pluralis di Cigugur, Kuningan, Jawa Barat Subjek penelitiannya adalah perwakilan masyarakat yang beragama Islam, Katolik, dan ADS (Agama Djawa Sunda). Pengumpulan data menggunakan teknik observasi, wawancara, dan dokumentasi. Hasil penelitian menunjukkan bahwa metode penanaman karakter peduli sosial di lingkungan masyarakat Cigugur Kuningan yaitu melalui keteladanan dan pembiasaan. Keteladanan karakter peduli sosial melalui pemuka agama Islam, Katolik, dan ADS. Sedangkan pembiasaan karakter peduli sosial melalui kegiatan-kegiatan di masyarakat yaitu gotong royong membangun tempat ibadah dan rumah warga, pembuatan jalan dan parit, serta saling membantu saat ada warga masyarakat yang terkena musibah.
\end{abstract}

Kata Kunci: pendidikan karakter, peduli sosial, dan masyarakat pluralisme

\section{IMPLEMENTATION OF SOCIAL CARE CHARACTER EDUCATION IN THE PLURALIST COMMUNITY OF PLURALISM IN CIGUGUR KUNINGAN}

\begin{abstract}
This study aims to describe the implementation of social care character education in the community. This research is a qualitative research using analytical descriptive method which takes the pluralist community setting in Cigugur, Kuningan, West Java. The research subjects were representatives of the Muslim, Catholic and ADS communities (Agama Djawa Sunda). Data collection uses observation, interview, and documentation techniques. The results showed that the method of planting socially caring characters in the community of Cigugur Kuningan was through exemplary and habituation. The exemplary character of social care through Islamic, Catholic and ADS religious leaders. While the habit of caring social characters through activities in the community, namely mutual cooperation to build places of worship and homes, making roads and trenches, and helping each other when there are residents affected by the disaster.
\end{abstract}

Keywords: character education, social care, and pluralist community

\section{PENDAHULUAN}

Gambaran umum tentang Negara Indonesia tidak dapat dilepaskan dari pluralitas. Kemajemukan etnis, suku, dan agama dengan segala alirannya merupakan realitas keindonesiaan yang tidak bisa dipungkiri siapa pun. Keragaman tersebut pada gilirannya melahirkan keragaman budaya, pandangan, dan bahkan dunia kehidupannya sendiri yang satu dengan yang lain tidak bisa dianggap sebagai sesuatu hal yang kecil atau sederhana. Tidak heran jika perbincangan pluralisme itu sendiri sampai saat ini masih menjadi isu yang cukup menarik. Setidaknya untuk kasus yang telah terjadi di Indonesia. Adanya macam-macam agama dan kepercayaan di Negara Indonesia adalah suatu kenyataan.

Dewasa ini semakin jelas arus pemahaman dan sikap yang menegaskan bahwa agama mempunyai makna dalam kehidupan bermasyarakat. Setiap agama membawa misi sebagai pembawa kedamaian dan keselarasan hidup, bukan saja antarmanusia, tetapi juga antar sesama makhluk Tu- 
han penghuni semata ini. Namun, pada aspek historisnya, misi agama tidak selalu artikulatif. Selain sebagai alat pemersatu sosial, agama pun menjadi unsur konflik. Schimmel (Kahmad, 2009:169), menyebutkan bahwa dua unsur tersebut (alat pemersatu sosial dan unsur konflik) menyatu dalam agama. Berkaitan dengan hal itu, salah satu yang menjadi problem paling besar dalam kehidupan beragama dewasa ini, yang ditandai oleh kenyataan pluralisme, yaitu bagaimana teologi suatu agama mendefinisikan diri di tengah-tengah agama lain.

Pluralisme kerap dianggap sebagai ancaman besar bagi sebagian besar umat beragama yang ada di Indonesia, karena diyakini bahwa pluralisme menganggap bahwa semua agama sama dalam kemajemukannya. Pemaparan di atas, semakin menguatkan argumen tentang kebutuhan manusia akan agama. Kebutuhan tersebut merupakan suatu kesatuan yang tidak bisa dipisahkan antara agama sebagai ruh bagi tata kehidupan manusia. Namun, dalam perjalanannya, pemahaman manusia tentang agama terus mengalami pergeseran.

Penjelasan tentang etika kerukunan hidup antarumat beragama harus memuat hal-hal berikut: (1) Posisi yang sama dari setiap agama dan kepercayaan. Semua mendapat perlindungan dan jaminan yang sama tanpa pandang bulu. (2) Posisi dengan hak dan tugas yang sama pula harus diberikan kepada tiap warga yang memeluk agama dan kepercayaan yang berlainan. Ia terjamin untuk memeluk agamanya, dan terjamin untuk melakukan ibadah menurut agama dan kepercayaannya.

Bila jaminan untuk kebebasan memeluk agama dan beribadah dikaitkan dengan hakikat yang luhur dari tiap-tiap agama dan kepercayaan, demikian pula bila dikaitkan dengan sila peri kemanusiaan yang adil dan beradab, maka tiap paksaan terhadap warga dalam bentuk apa pun tidak sesuai dengan martabat yang luhur dari agama dan kepercayaan dan tidak sejalan dengan martabat manusia yang beradab. Sehubungan dengan itu, maka keanggotaan dari suatu agama dan kepercayaan tertentu bukan berdasarkan ketentuan atau pengandaian dari pihak mana pun juga, tetapi berdasarkan kesukarelaan tiap orang yang mau jadi anggota. Mengingat bahwa tiap agama dan kepercayaan bukan merupakan tujuan akhir manusia, melainkan hanya alat pemersatu manusia dengan Tuhan, maka seyogianya agama menjalankan fungsi pelajaran terhadap pribadi dan perkembangan pribadi manusia dalam hubungannya dengan Tuhan. Oleh sebab itu, pada satu pihak perlu dijamin kebebasan bagi tiap usaha yang wajar yang dilakukan oleh tiap-tiap golongan agama untuk membina kepribadian dan perkembangan kepribadian tiap-tiap anggota sesuai dengan keyakinannya (Budiyono, 1983:19).

Di pihak lain juga perlu dijamin kemerdekaan pribadi dari tiap-tiap penganut yang dalam perkembangannya mungkin mengubah keyakinannya terhadap polapola nilai tertentu, termasuk pola nilai yang terdapat dalam agama tertentu yang dianutnya. Mencegah tafsiran yang salah, cemooh, dan ejekan terhadap ajaran agama lain. Oleh karena itu, dalam membina kerukunan hidup antarumat beragama dan kepercayaan, penyadaran sebagai makhluk sosial dan sebagai warga negara merupakan kunci utama. Karena sebagai warga negara yang baik pasti berusaha untuk ikut serta menciptakan kerukunan dan tidak menimbulkan kekacauan di negeri sendiri (Suryana, 2011:134-135). Kenyataan itu saja kiranya sudah dapat dilihat sebagai tanda bahwa hubungan antarumat beragama tidak dianggap hal kecil, melainkan merupakan 
kepedulian yang sangat penting baik dari perspektif teologis.

Kerukunan di antara masyarakat yang pluralisme tentu saja akan memengaruhi rasa kepedulian mereka terhadap sesama warga. Jika warga masyarakat bisa hidup rukun dan damai, maka tentu karakter peduli sosial mereka pun akan ikut tertanam dalam kepribadian. Sekarang banyak terjadi tindakan kurangnya rasa peduli sosial terhadap orang lain (Eryana, 2014:3). Bentuk tindakan kurangnya rasa peduli sosial salah satu contohnya adalah kegiatan gotongroyong yang semakin diabaikan di dalam lingkungan masyarakat. Mereka lebihmengutamakan kepentingan pribadi dibandingkan mementingkan kepentingan bersama. Tindakan tersebut dapat mengurangi rasa persatuan dan kesatuan antarumat manusia. Karakter peduli sosial diharapkan ada pada setiap individu, karena banyak masyarakat sekarang ini yang kurang peduli terhadap sesamanya yang disebabkan berbagai hal. Tujuan pendidikan karakter yang berkaitan dengan kesadaran pada setiap individu dikelola dengan menanamkan nilainilai peduli sosial dan nilai tradisional yang positif. Penanaman karakter peduli sosial di kalangan masyarakat bisa dilakukan dengan berbagai cara. Karakter peduli sosial pada individu terletak pada pendidikan di sekolah maupun di dalam lingkungan keluarga dan juga masyarakat. Manusia yang berkarakter dan mempunyai rasa peduli sosial terhadap orang lain tidak dapat terwujud secara tiba-tiba.

Atas dasar uraian permasalahan tersebut, peneliti terdorong untuk melakukan penelitian mengenai "Implementasi Pendidikan Karakter Peduli Sosial pada Masyarakat Pluralisme di Cigugur Kuningan". Peneliti mengambil sampel sebuah masyarakat yang bersifat plural yang mewakili masyarakat-masyarakatplural lainnya yang ada di Indonesia untuk dikaji dari sudut pandang pendidikan karakter. Peneliti melakukan observasi di Cigugur Kuningan, Jawa Barat untuk mengumpulkan data dan fakta tentang pelaksanaan pendidikan karakter peduli sosial pada masyarakat pluralisme di Cigugur Kuningan. Adapun tujuan penelitian ini adalah untuk mendeskripsikan pengimplementasian pendidikan karakter peduli sosial pada pasyarakat pluralisme di Cigugur Kuningan.

\section{METODE}

Penelitian ini menggunakan pendekatan kualitatif dan metode deskriptif analitis. Pendekatan kualitatif berorientasi pada gejala-gejala yang bersifat alamiah sehingga sifatnya naturalistik dan mendasar atau bersifat kealamian serta tidak bisa dilakukan di labotarium melainkan harus turun ke lapangan.

Penelitian ini dilakukan di Kecamatan Cigugur Kabupaten Kuningan Provinsi Jawa Barat. Subjek penelitian adalah warga Cigugur yang memiliki latar belakang agama yang beragam, terutama yang beragama Islam, Katolik, dan ADS (Kepercayaan/ Agama Djawa Sunda).

Pengumpulan data dengan Teknik observasi, wawancara, dan dokumentasi. Observasi dilakukan di lingkungan masyarakat yang berpusat di Cigugur Kabupaten Kuningan. Adapun serta mewancara dilakukan dengan sejumlah tokoh masyarakat Cigugur dan pemuka agama. Data yang terkumpul kemudian dianalisis secara deskriptif kualitatif.

\section{HASIL DAN PEMBAHASAN \\ Hasil}

Cigugur sejak dulu sampai sekarang dikenal sebagai suatu tempat di Kabupaten Kuningan yang memiliki banyak penduduk dengan agama yang berbeda-beda. Namun 
kerukunan warga di Cigugur sampai sekarang selalu terjaga baik. Cigugur diibaratkan sebagai miniaturnya Indonesia. Suatu daerah yang etnisnya banyak dan agamanya berbeda-beda. Namun, warga di Cigugur tetap saling menghormati, hidup rukun, dan damai. Seperti pada perayaan Idul Fitri, umat non-Muslim ikut merayakan dengan bersilaturahmi ke rumah warga Muslim. Kerukunan antarwarga berbeda agama di Cigugur tidak hanya ditunjukkan warganya pada hari raya Idul Fitri, tetapi selalu terjaga pula dalam suasana sehari-hari serta pada hari-hari raya agama lainnya.

Untuk memperoleh data, penulis mewawancarai beberapa orang warga di Cigugur. Berikut adalah hasil wawancara dengan mereka.

Pertama, wawancara dengan Bapak Ari Rianto, Sekretaris Desa Cisantana Cigugur. Menurut Beliau kunci kerukunan di Cigugur adalah saling membantu dengan sesama warga, tidak pernah menghujat orang lain, tidak pernah memaksakan suatu agama kepada orang lain, tidak pernah mendoktrin, tidak mudah terpengaruh, tidak memicu terjadinya konflik, tidak membawa isu agama saat bermusyawarah, dan mereka selalu berhati-hati ketika prosesproses komunikas memasuki wilayah keagamaan.

Masyarakat bisa hidup berdampingan walau memiliki agama yang berbeda-beda yakni Islam, Katolik, dan Kepercayaan, karena tidak pernah saling mengganggu ritual agama masing-masing dan selalu saling membantu saat ada tetangga yang membutuhkan. Misalnya ketika ada orang yang "live in" dirumah warga, maka mereka menjamu tamu tersebut dengan baik, tidak peduli apakah agama tamu dan pemilik rumah sama atau berbeda.

Meskipun saat ini di media sosial banyak terjadi konflik di tengah masyarakat karena masalah agama, namun hal itu tidak berpengaruh bagi kerukunan masyarakat Cigugur, karena semua warga memiliki sifat tidak mudah terpengaruh. Di saat ada isu yang sekiranya akan memicu konflik, maka semua warga akan berusaha untuk meredam isu tersebut.

Ketika ada salah satu tempat ibadah yang butuh perbaikan, maka semua warga akan bergotong royong membantu tanpa melihat apakah itu tempat ibadah orang Islam, Katolik, ataupun ADS. Cara seperti ini merupakan salah satu cara atau metode penanaman karakter peduli sosial di masyarakat Cigugur Kuningan.

Melalui pengembangan sikap saling menghargai, pengendalian diri, tolong-menolong, kebersamaan dalam kegiatan sosial kemasyarakatan, dan melalui kerja sama yang saling menguntungkan, potensi yang cukup kuat untuk terjadinya konflik yang berkembang dalam suatu kelompok keagamaan terhadap kelompok keagamaan lainnya dapat diminimalisasi, sehingga konflik secara terbuka antarkelompok keagamaan di Kecamatan Cigugur dapat dihindarkan. Konflik tersebut hanya akan terjadi jika ada orang-orang dari luar yang dengan sengaja melakukan penghasutan sehubungan dengan kehidupan kelompok keagamaan. Jadi, selama tidak ada pihak-pihak dari luar yang turut campur dalam kehidupan sosial keagamaan, tidak akan terjadi konflik di Cigugur.

Kedua, wawancara dengan Pak Agus Susanto, Ketua Badan Usaha Milik Desa (BUMDES) Cisantana, Cigugur, Kuningan. Sebagai bentuk kepedulian desa terhadap kesejahteraan masyarakat Cigugur, adanya BUMDES diharapkan mampu memberikan pinjaman modal usaha untuk kepentingan bersama tanpa bunga. Peminjam bisa mengembalikan uang modal tersebut saat ia sudah memiliki uang. 
BUMDES ingin menaikkan pamor pariwisata yang ada di Cigugur, seperti Taman Cisantana, Gua Maria, dan Sawer Rahmat. Pada saat bermusyawarah tentang Gua Maria, semua perwakilan warga dilibatkan, bukan hanya warga Katolik saja. Selain pariwisata, BUMDES juga mengadakan PAMDES, yaitu Perusahaan Air Minum Desa. Semua warga desa boleh menggunakannya, tanpa ada pilih kasih.

Karakter peduli sosial tidak tumbuh begitu saja, namun perlu adanya keteladanan dari pihak tokoh masyarakat dalam mencontohkan rasa peduli sosial bagi warga masyarakat. Salah satunya dengan bersikap adil kepada setiap warga, baik warga yang beragama Islam, Katolik, maupun ADS.

Ketiga, wawancara dengan Rama Andreas Dedi, OSC yang biasa dipanggil Rama Dedi, seorang imam Katolik yang memimpin umat Katolik di Cigugur. Beliau adalah orang Sunda asli yang berkarya di Tatar Sunda sebagai seorang biarawan.

Ketika ada Upacara Seren Taun, Gereja Katolik pun ikut bersyukur dengan mengadakan ibadat keagamaannya sendiri yang disebut Misa syukur. Dalam Misa syukur mereka menggunakan bahasa Sunda sebagai bahasa pengantar dengan lagu-lagu Sunda yang diiringi oleh gamelan. Imam dan para petugas lainnya menggunakan pakaian daerah sehingga suasana Sunda sangat terbangun, apalagi dekorasi gereja pun bernuansa Sunda. Biasanya setelah Misa syukur di gereja, pastur kepala paroki akan bergabung dalam acara doa lintas agama dan kepercayaan, serta melantunkan doa secara Katolik.

Dalam kegiatan sosial, umat Katolik di Cigugur pun selalu siap sedia membantu tanpa memikirkan siapa yang akan ditolong. Misalnya ketika terjadi bencana banjir di beberapa daerah Kuningan. Umat Katolik Cigugur pun langsung turun tangan membantu orang-orang yang memerlukan. Ada yang memberi materi, ada pula yang memberikan tenaganya melayani orangorang di posko-posko yang sudah dibentuk. Ketika Rama Dedi mengirimkan bantuan, beliau tidak mengatakan bantuan tersebut dari umat Katolik Cigugur, tetapi mengatakan bahwa sumbangan itu berasal dari umat Cigugur. Beliau mengatakan hal itu karena dalam kesulitan, orang yang membantu sesama tidak perlu mengumumkan identitasnya, apalagi dengan membawa nama organisasi untuk dipublikasikan. Baginya hal seperti ini tidak perlu dipublikasikan, karena peduli sosial membutuhkan karsa, bukan kata.

Keempat, wawancara dengan Bapak Darsono, salah satu umat Islam yang ada di Cigugur. Beliau menyatakan bahwa masyarakat di Cigugur bisa hidup rukun walau anggota masyarakatnya berbeda agama. Halyang mendasarinyayaitu:(1) merasa ada satu ikatan darah, satu keluarga, dan semuanya bersaudara; (2) jarang ada pendatang sehingga masing-masing kenal dengan semua tetangga; (3) semangat bergotong-royong, jika ada yang membangun rumah maka para tetangga ikut bantu dalam bentuk makanan atau uang; (4) jika ada pendatang, maka pendatang itu yang harus menyesuaikan diri dengan kebiasaan atau tradisi di Cigugur; dan (5) semua masyarakat Cigugur memiliki karakter mudah bergaul.

Dalam acara seren taun, semua warga Cigugur ikut berpartisipasi, misal dengan mencari dana untuk pelaksanaan seren taun tersebut. Dengan prinsip kebersamaan dan tidak membeda-bedakan orang, maka akan terbentuk rasa nyaman untuk semua anggota masyarakat. Karakter peduli sosial bisa dibangun dengan ikut merasakan duka warga lain. Contohnya yaitu saat ada yang 
meninggal, semua warga akan ikut mengantarkan ke pemakaman, tidak peduli agama apa yang dianutnya.

Kelima, wawancara dengan Suster Bernadeth, seorang pemimpin Susteran Ursulin di Desa Cisantana, Cigugur. Suster Bernadeth dilahirkan di Desa Cisantana. Jadi Suster Bernadeth adalah putri Sunda Cisantana. Suster Bernadeth sangat peduli terhadap anak-anak cacat. Selama 16 tahun di Filipina beliau berkarya untuk anakanak.

Menurutnya penyandang cacat sebagai salah satu penyandang masalah kesejahteraan sosial perlu mendapat perhatian agar ia dapat melaksanakan fungsi sosialnya. Penyandang cacat adalah orang yang kondisinya tidak normal sehingga menghambat kemampuannya untuk melaksanakan fungsi sosialnya di masyarakat. Ia masih bisa berpikir normal, dapat merasakan, dan dapat berbuat sesuatu walaupun ada bagianbagian tertentu dari tubuhnya yang kurang berfungsi namun ada juga bagian-bagian tubuh lain yang masih dapat difungsikan. Penyandang cacat tubuh secara psikis akan mengalami rasa rendah diri dan kesulitan dalam menyesuaikan diri di masyarakat, karena perlakukan masyarakat atau lingkungan sekitar berupa celaan atau belas kasihan ketika memandangnya.

Pengalaman yang membuat Suster Bernadeth merasa prihatin adalah ketika menemukan banyak orang tua yang tidak dapat menerima keadaan anaknya sehingga tidak memedulikannya. Di Filipina banyak terjadi anak dipasung atau disembunyikan di bagian bawah rumah panggung bersama dengan hewan peliharaan mereka. Keadaan yang menyedihkan itu membuat Sr. Bernadeth dkk berusaha menyadarkan orang tua anak-anak cacat tersebut bahwa anak-anak itu merupakan anugerah dan titipan dari
Tuhan yang harus dirawat. Dalam pertemuannya dengan anak-anak dan orang tua mereka, anak-anak diberikan terapi atau kegiatan yang sangat berguna bagi mereka. Begitu pula dengan orang tua mereka, yang diberi kegiatan yang sangat berguna untuk mendidik anak-anak meraka atau untuk meningkatkan kesejahteraan keluarga mereka.

Pengalaman itulah yang membuat Sr. Bernadeth melanjutkan misinya dalam menyadarkan para orang tua anak-anak cacat. Di rumah dan di kantor kepala desa, Suster Bernadeth dibantu oleh orang-orang yang peduli terhadap anak-anak cacat itu. Mereka berasal dari berbagai kalangan dengan agama yang berbeda-beda. Mereka membantu anak-anak tersebut tanpa pamrih. Pengalaman ini membuktikan bahwa toleransi dan peduli sosial mendasari mereka dalammengupayakan kehidupan lebih baik bagi anak-anak cacat dengan orang tuanya.

Keenam, wawancara dengan Ibu Nina, seorang pegawai negeri beragama Katolik yang mengajar di SDN 2 Cisantana, Cigugur, Kuningan. Ibu Nina lahir dan berkarya di Cigugur setelah menimba ilmu di SPG Santa Angela, Bandung.

Sebagai umat beragama, Ibu Nina cukup aktif mengikuti organisasi keagamaan di antaranya menjadi anggota perkumpulan Wanita Katolik (WK). Banyak kegiatan dalam perkumpulan tersebut, di antaranya belajar menjahit, merangkai bunga, belajar bahasa Inggris dll. Sebagai anggota WK, Ibu Nina pun kadang kala mengikuti seminar yang diselenggarakan oleh Pemerintah Daerah Kuningan, di antaranya seminar untuk kaum perempuan. Hasil dari seminar itu pun dibagikan kepada sesama perempuan di sekolah tempatnya mengajar, di sekitar rumah kepada para tetangga, dan kepada teman-teman segereja di mana ia 
menjalankan ibadahnya. Apa yang dilakukannya karena kepeduliannya terhadap kemajuan kaum perempuan di desanya.

Ketujuh, wawancara dengan Sr. Yuliana, kepala sekolah di PKBM Bina Cahya. PKBM adalah Pusat Kegiatan Belajar Masyarakat yang ada di Cigugur. Beliau sudah menjabat sebagai kepala sekolah PKBM selama tiga tahun terakhir. Dulu PKBM bernama Kelas Pembangunan dan pada tahun 2009 namanya berubah menjadi PKBM Bina Cahya. Visi PKBM adalah semangat persaudaraan dan semangat kekeluargaan. PKBM menyelenggarakan program kesetaraan SMP (Paket B), program kesetaraan SMAIPS(PaketC), pendidikan kecakapan hidup/ keterampilan, pendidikan kewirausahaan/ kursus, dan taman bacaan masyarakat.

Di program pendidikan umum (paket B dan paket C), salah satu mata pelajarannya yaitu mata pelajaran Budi Pekerti. Budi Pekerti tidak lepas dari ajaran agama. Program pendidikan keterampilan terbagi dua kategori, yaitu putera (pertukangan kayu, gambar teknik, dan kewirausahaan) dan puteri (tata busana dan tata boga).

PKBM Bina cahya merupakan sekolah semi formal dan formal. Para siswa diberikan seragam dan melaksanakan ujian agar secara psikologis mereka merasa sama dengan siswa-siswa dari sekolah lain.

Siswa-siswa yang sekolah di PKBM berasal dari empat agama yang berbeda, yaitu Katolik, Kristen, Islam, dan Kepercayaan. Hal ini sesuai dengan semangat persaudaraan dan kekeluargaan yang menjadi visi sekolah sehingga semua anak dengan agama apa pun boleh sekolah di PKBM. Meskipun PKBM dipimpin oleh suster, namun bagi siswa yang beragama Islam diberi waktu untuk melaksanakan salat Jumat (hari Jumat pulang sekolah lebih awal) dan bagi siswi yang beragama Islam juga diperbolehkan memakai hijab. Sr. Yuliana akan langsung menegur para siswi Muslimah yang memakai hijab tetapi tidak sesuai dengan syariat Islam, misalnya ketika hijab yang mereka gunakan tidak menutup dada.

Menurut Sr. Yuliana, setiap siswa harus bisa memahami agama orang lain (literasi agama), sehingga dengan memahami agama orang lain maka akan muncul karakter toleransi dalam diri setiap siswa. Jika siswa tidak bisa memahami agama orang lain, maka akan muncul suatu praduga atau prasangka terhadap agama orang lain yang tidak baik. Diharapkan dengan bertemu dengan orang yang "berbeda", maka akan memahami adanya perbedaan tersebut.

Sr. Yuliana membudayakan para siswa untuk mau bertanya, mau menjelaskan, dan mau memahami agama orang lain. Hal ini dilakukan agar setiap orang tidak salah dalam memandang agama orang yang berbeda-beda. Tujuan memahami agama orang lain (literasi agama) adalah untuk memahami ajaran agama yang lain yang berbeda.

Kegiatan siswa selain bersekolah adalah ikut berpartisipasi dalam acara di masyarakat, yaitu menampilkan kesenian saat seren taun, membuat kue kering saat Idul Fitri dan Natal, dan ikut perlombaan dalam HUT RI. Para siswa tata busana juga memiliki proyek untuk membuat kaos praktik, baju batik, kaos olahraga, celemek, dan baju seragam untuk anak TK.

Kedelapan, wawancara dengan Ibu Ela Romlah, salah seorang bidan Puskesmas Desa Cisantana. Beliau adalah orang Bandung yang bersuamikan orang Cisantana. Ibu Ela adalah seorang penghayat. Penghayat artinya penganut aliran kepercayaan Sunda Wiwitan atau ADS. Yang mengejutkan bagi peneliti, ternyata suami dan kedua anak Ibu Ela menganut Agama Katolik. Perbedaan dalam satu keluarga tersebut tidak memengaruhi kerukunan keluarga mereka. 
Tampak sikap toleransi yang besar ditunjukkan oleh keluarga tersebut. Dalam obrolan peneliti dengannya, dengan tegas ia banyak mengungkapkan tentang aliran Sunda Wiwitan atau ADS yang dianutnya.

Orang di luar ADS sering kali merasa salah mengerti tentang aliran kepercayaan ini. Pada umumnya orang di luar ADS menganggap bahwa ADS adalah singkatan dari Agama Djawa Sunda, yang diartikan sebagai agama milik orang Jawa dan orang Sunda. Padahal Agama Djawa Sunda ini adalah akronim dari sebuah ungkapan, yaitu "Anjawat lan anjawab roh susun-susun kang den tunda" (memilih dan menyaring roh yang tersusun dan yang tertunda, yang ada di seluruh alam semesta termasuk dalam diri manusia). Yang dimaksud dengan "memilih" dan "menyaring" ini adalah sebuah tindakan manusia yang berlangsung dalam proses "meditasi" atau "semedi". Tujuan tindakan ini adalah untuk "menyempurnakan" roh-roh tersebut supaya menjadi roh yang layak atau pantas bagi manusia dan mencerminkan kemanusiaan.

Setiap bulan Rayagung masyarakat di Cigugur merayakan Upacara Adat Seren Taun. Pada dasarnya Upacara Seren Tahun adalah upacara syukur panen padi yang dilaksanakan masyarakat Sunda khususnya di wilayah desa Adat Sunda. Di Kuningan, upacara ini dilakukan oleh komunitas masyarakat di Desa Cigugur. Upacara Seren Taun di Desa Cigugur Kuningan dipusatkan di Pendopo Paseban Tri Panca Tunggal tempat kediaman Pangeran Djatikusumah. Bulan Rayagung adalah bulan terakhir dalam penanggalan kalender Sunda kuno. Upacara Seren Taun sarat akan nilai-nilai sakral, budaya, kesenian, dan pendidikan. Seren Taun merupakan salah satu warisan budaya masyarakat agraris Jawa Barat sebagai ungkapan rasa syukur pada Tuhan Yang Maha Esa atas hasil panen dalam setahun. Upacara Seren Taun merupakan acara penyerahan hasil bumi berupa padi untuk disimpan ke dalam lumbung atau dalam bahasa Sunda disebut leuit.

Dalam ceritanya, Ibu Ela menjelaskan bahwa setiap umat Katolik merayakan Natal, yang piket di sekitar gereja adalah bapak-bapak yang beragama Islam dan kaum penghayat. Ibu-ibu dan anak-anak menyediakan konsumsi bagi umat Katolik yang selesai merayakan ibadat agamanya. Begitu juga sebaliknya, ketika umat Islam merayakan hari raya Idul Adha, umat Katolik dan penghayat membantu memotong kurban. Ketika umat penghayat merayakan Upacara Seren Tahun, umat Katolik dan umat Muslim pun turut bersyukur atas berkat yang mereka terima dengan merayakannya sesuai ajaran mereka. Tampak sekali toleransi keagamaan yang begitu kuat di antara masyarakat Cigugur.

Ada kisah lain yang diceritakan Ibu Ela. Ketika ada pembuatan jalan di Desa Cisantana, pemerintah setempat dan semua warga bergotong-royong. Ada yang memberikan material, ada yang memberikan makanan dan minuman, ada pula yang memberikan tenaga tanpa meminta bayaran. Hasilnya luar biasa, jalan itu dapat terwujud karena masyarakat memiliki rasa peduli sosial terhadap kenyamanan semua warga dalam menggunakan transportasi.

\section{Pembahasan}

Di era global ini, warisan yang diajarkan leluhur bangsa Indonesia, "Ing ngarsa sung tuladha, ing madya mangun karsa, tut wuri handayani" relevan dalam mengedepankan keteladanan dan pembiasaan sebagai upaya menanamkan pendidikan karakter pada masyarakat pluralisme di Cigugur Kuningan. Pengembangan karakter memerlukan pembiasaan penalaran moral 
dan keteladanan tindakan moral di lingkungan mereka.

Karakter anak-anak dapat dikembangkan sejak dini hingga remaja (Afandi, 2011: 87). Secara kontekstual, mereka diibaratkan ranting yang sangat mudah diluruskan, setelah dewasa ibarat batang yang sulit diluruskan. Karena itu, sejak anak-anak hingga remaja, meski penalaran moral lebih efektif meningkat jika mereka upayakan sendiri lewat pembiasaan menghadapi dilema-dilema moral daripada mencontoh orang yang lebih dewasa, tindakan moral sebagai representasi karakter mereka akan berkembang lebih luhur dan efektif jika mendapat teladan yang luhur pula di lingkungan mereka.

Penanaman karakter peduli sosial kepada anak membutuhkan keteladanan dari orang tua, guru, dan masyarakat (Kurniawati, 2015:369). Penanaman karakter tersebut tidak hanya berlangsung di keluarga, tetapi juga di lingkungan sekolah dan masyarakat, sehingga dengan keteladanan serta pembiasaan akan terwujud masyarakat yang damai walau dengan latar belakang agama, etnis, dan budaya yang berbeda.

Berdasarkan hasil observasi masyarakat di Cigugur, Kuningan, Jawa Barat tersebut, ternyata masyarakat di sana hidup dalam sebuah perbedaan. Yang menjadi perbedaan mendasar pada masyarakat Cigugur adalah perbedaan agama pada masing-masing individunya. Perbedaan tersebut tidak hanya terdapat pada masingmasing warganya melainkan perbedaan tersebut juga ada dalam satu keluarga. Misalnya, ayah dan ibu menganut agama Islam, tetapi anak-anak mereka ada yang menganut agama Katolik, Hindu, Buddha, atau agama Islam yang juga sesuai dengan agama yang dianut oleh orang tua mereka. Dan itu sudah menjadi hal yang biasa bagi warga masyarakat di Cigugur Kuningan.
Meskipun masyarakat Cigugur hidup dalam perbedaan, namun kehidupan masyarakatnya tetap rukun dan damai, tanpa ada konflik sedikit pun, karena kehidupannya dibangun atas dasar rasa toleransi yang tinggi. Perbedaan yang ada pada masyarakat Cigugur tersebut tidaklah menjadikan mereka hidup dalam ketegangan hingga menimbulkan suatu konflik seperti konflik-konflik yang sering terjadi dewasa ini yang dilatarbelakangi oleh perbedaan agama, namun kehidupan mereka justru sangat harmonis, bisa hidup secara berdampingan, dan sangat menjunjung tinggi pluralisme beragama. Masyarakat Cigugur bukan hanya mengakui keberadaan hak agama orang lain yang berbeda, tetapi juga terlibat dalam usaha memahami perbedaan dan persamaan dari setiap masing-masing penganut agama yang ada. Faktanya, bahwa setiap masyarakat yang berbeda agama tersebut dapat berinteraksi secara positif dalam lingkungan kemajemukannya.

Dalam pendidikan karakter mencakup tiga muatan yaitu moral reasoning (pengetahuan moral), moral feeling (perasaan moral) dan moral behavior (perilaku moral) (Megawangi, 2010:5). Karakter adalah nilai dasar yang membangun pribadi seseorang yang terbentuk oleh faktor keturunan maupun lingkungan alam dan lingkungan sosial. Karakter membedakan individu satu dengan lainnya dan menjadi ciri khas dalam perilaku sehari-harinya. Pendidikan karakter adalah pendidikan akhlak yang melibatkan aspek pengetahuan, perasaan dan tindakan. Pendidikan karakter merupakan sistem penanaman nilai karakter kepada warga sekolah yang meliputi tiga komponen pengetahuan, kesadaran dan tindakan untuk melaksanakan nilai-nilai tersebut (Marzuki \& Haq, 2018).

Pendidikan karakter menjadi tanggung jawab tiga pusat pendidikan yaitu 
lingkungan keluarga, lingkungan sekolah dan lingkungan masyarakat (Raharjo, 2010: 237). Keluarga merupakan lingkungan pendidikan pertama yang menanamkan nilai karakter, selanjutnya sekolah menjadi pusat pendidikan kedua yang menanamkan, menguatkan serta mengembangkan karakter dasar seorang anak yang telah dibentuk di dalam keluarga. Terakhir lingkungan masyarakat yang merupakan tempat interaksi antar individu serta penerapan nilai dan norma juga harus bersinergi untuk mencapai keberhasilan pendidikan karakter. Dalam penyelenggaraan pendidikan karakter diperlukan sinergi ketiga pusat pendidikan tersebut. Kesemuanya perlu berada dalam satu kekompakan melalui jalinan komunikasi dan kolaborasi yang harmonis dalam mendukung program-program pendidikan karakter. Pendidikan karakter menjadi hal penting dewasa ini, melihat kemerosotan moral yang dialami masyarakat kita. Tri pusat pendidikan harus mulai membenahi terutama sekolah-sekolah yang merupakan lembaga pendidikan yang diberi tugas oleh pemerintah untuk mewujudkan generasi berakhlak mulia harus lebih intensif dan serius dalam melaksanakan pendidikan karakter (Palunga \& Marzuki, 2017). Dalam implementasinya, pendidikan karakter dapat dikembangkan melalui tahap pengetahuan (knowing), pelaksanaan (acting), dan kebiasaan (habit). Pendidikan karakter tidak terbatas pada pengetahuan saja, sebab seseorang dengan pengetahuan yang baik belum tentu memiliki tindakan yang sesuai pengetahuannya jika tidak terlatih untuk melakukan kebaikan itu sendiri.

Peduli sosial sebagai salah satu inti dalam implementasi pendidikan karakter adalah sikap dan tindakan yang selalu ingin memberi bantuan pada orang lain dan masyarakat yang membutuhkan (Kurniawan,
2015:44). Peduli sosial ini merupakan implementasi kesadaran manusia sebagai makhluk sosial yang tidak dapat hidup sendiri. Manusia membutuhkan orang lain untuk memenuhi kebutuhannya sehingga ada sifat saling tergantung antara satu individu dan individu lain. Sebagai makhluk sosial tentunya manusia akan ikut merasakan penderitaan dan kesulitan orang lain sehingga ada keinginan untuk memberikan pertolongan dan bantuan kepada orangorang yang kesulitan. Manusia mempunyai rasa empati, rasa merasakan apa yang dirasakan orang lain dan dengan itu tergeraklah hatinya untuk menolong orang lain. Oleh karena itu, pada hakikatnya manusia adalah makhluk yang suka tolong-menolong (Mustari, 2011:3). Nilai inti peduli sosial dalam pendidikan karakter di Indonesia dapat diturunkan menjadi nilai-nilai turunan yaitu penuh kasih sayang, perhatian, kebijakan, keadaban, komitmen, keharuan, kegotongroyongan, kesantunan, rasa hormat, demokratis, kebijaksanaan, disiplin, empati, kesetaraan, suka memberi maaf, persahabatan, kesahajaan, kedermawanan, kelemahlembutan, pandai berterima kasih, pandai bersyukur, suka membantu, suka menghormati, keramahtamahan, kemanusiaan, kerendahhatian, kesetiaan, moderasi, kelembutan hati, kepatuhan, kebersamaan, toleransi, dan punya rasa humor (Samani \& Hariyanto, 2014:138). Nilai-nilai turunan tersebut dapat dijadikan indikator mengenai karakter peduli sosial. Individu yang memiliki peduli sosial akan mampu berhadapan dengan lingkungannya dan menampakkan sifat-sifat positif seperti yang dirinci di atas.

Sikap peduli sosial dan suka menolong merupakan tulang punggung keteguhan suatu masyarakat. Jika tidak ada sikap ini, masyarakat akan ambruk (Samani \& Hariyanto, 2014:190). Dengan penguatan 
nilai karakter peduli sosial kepada peserta didik maka di masa depan akan terbentuk generasi-generasi baru yang saling menghormati, saling membantu dan bekerjasama untuk mensejahterakan lingkungan masyarakat di sekitarnya.

Pendidikan karakter peduli sosial diasumsikan dapat membentuk kepribadian generasi mendatang yang lebih berkualitas. Namun demikian, proses penanaman nilai peduli sosial pada individu tidak dapat dilakukan secara cepat dan tiba-tiba. Di masyarakat, proses tersebut harus dilakukan melalui tahapan berjenjang sebagai berikut (Damayanti, 2014:59-61).

- Tahap penanaman yaitu dengan membiasakan individu berbuat kebaikan. Pada tahap ini aspek keteladanan dengan prinsip ing ngarsa sung tuladha sangat penting dan sangat diperlukan. Faktor keteladanan ini akan menjadi landasan yang fundamental bagi individu dalam menanamkan nilai peduli sosial yang sedang atau telah diterima dari lingkungan di mana ia berada.

- Tahapan penumbuhanyaitu dengan memberikan tanggung jawab kepada individu sesuai dengan tingkat perkembangan usianya. Dengan memberikan tanggung jawab maka nilai-nilai yang telah ditanamkan dapat tumbuh dan melekat dalam dirinya menjadi jati diri.

- Tahap pengembangan, pada tahap ini nilai-nilai yang telah ditanamkan dan ditumbuhkan pada diri individu perlu dikembangkan menjadi nilai-nilai diri. Nilai-nilai tersebut harus tercermin pada sikap dan perilakunya dalam kehidupan sehari-hari. Pada tahap pengembangan ini individu diberi tugas dan tanggung jawab. Tugas dan tanggung jawab tersebut di samping untuk kepentingan diri sendiri, tetapi juga dikembangkan untuk kepentingan orang lain.
- Tahap pemantapan yaitu dengan memberikan kepercayaan dan tanggung jawab untuk melakukan kegiatan yang berhubungan langsung dengan kehidupan masyarakat.

Adapun strategi dalam penanaman peduli sosial dalam pengembangan karakter dapat dilakukan dengan cara-cara berikut (Damayanti, 2014:62-65).

\section{- Keteladanan}

Aktualisasi nilai peduli sosial yang telah ditanamkan pada individu perlu didukung oleh lingkungan yang memberikan keteladanan. Pengembangan karakter individu sangat memerlukan lingkungan yang sesuai antara nilai idea dengan realitas yang dihadapi. Apa yang didengar dan dilihat oleh individu lebih berpengaruh daripada apa yang disuruh dan dilarang kepada mereka. Maka tiga lingkungan pendidikan yaitu keluarga, sekolah dan masyarakat harus menjadi lingkungan normatif bagi mereka.

- Pembiasaan

Karakter tidak terbentuk dengan tiba-tiba tetapi memerlukan proses dan penahapan yang kontinyu. Oleh karena itu, perlu upaya pembiasaan sebagai perwujudan dari nilai-nilai sehari-hari. Sebagaimana proses perubahan pada umumnya, proses awal perubahan selalu memerlukan energi yang lebih besar. Proses pembiasaan pada awalnya dimulai dengan memberi faktor pendorong eksternal yang kuat sehingga terkesan seperti pemaksaan pada tataran tertentu, yang dimulai dengan proses berlanjut menjadi pembiasaan, yang akhirnya faktor penggerak eksternal bergeser menjadi faktor internal dari diri sendiri. Pada tahap ini berarti telah terjadi kesesuaian antara nilai peduli sosial yang dipahami sebagai konsep diri dengan sikap perilaku yang muncul sebagai karakter. 
Mendidik karakter seseorang membutuhkan waktu yang panjang, pengulangan terus-menerus, melalui pemberian teladan, bimbingan, dan bantuan yang sesuai dengan kebutuhan mereka. Pendidikan karakter tidak cukup dilakukan secara teoretis saja, tetapi harus dipraktikkan secara riil, sehingga benar-benar diperoleh pengalaman yang dapat dirasakan manfaat atau mudharatnya.

Kekuatan karakter yang dibentuk dalam lingkungan keluarga dan sekolah akan semakin baik jika ada dukungan dan dorongan dari lingkungan masyarakat sekitar. Satu lidi tidak akan memiliki daya untuk menghalau sampah, namun jika didukung oleh ratusan lidi yang lain maka akan membentuk suatu kekuatan untuk membersihkan sampah. Masyarakat yang terdiri dari sekelompok atau beberapa individu yang beragam akan memengaruhi tumbuh kembang karakter-karakter individu yang ada di lingkungan masyarakat. Berpijak dari tanggung jawab tersebut, sepantasnya lingkungan masyarakat yang baik dapat melahirkan berbagai kemasyarakatan yang mendukung tumbuh kembangnya karakter, seperti peringatan hari besar keagamaan di masjid, gereja, maupun di paseban; pembinaan rohani; dan kursus-kursus agama, sehingga lingkungan masyarakat bisa memberikan kontribusi positif bagi pendidikan karakter yang ada di sekitarnya. Jadi masyarakat juga mempunyai tanggung jawab yang sama dalam mendidik. Masyarakat sebagai lingkungan pendidikan yang kebih luas turut berperan dalam terselenggaranya proses pendidikan karakter.

Implementasi pendidikan karakter peduli sosial harus sejalan dengan orientasi pendidikan. Pola pembelajarannya dilakukan dengan cara menanamkan nilai-nilai moral dalam diri individu yang bermanfaat bagi perkembangan pribadinya sebagai makhluk individual dan sosial. Proses ini dilaksanakan melalui proses pemberdayaan dan pembudayaan sebagaimana digariskan sebagai salah satu prinsip penyelenggaraan pendidikan nasional serta berlangsung dalam tiga pilar pendidikan, yaitu satuan pendidikan, keluarga, dan masyarakat. Peneladanan dan pembiasaan sangat penting untuk proses pembentukkan karakter. Hal ini tidak bisa terbentuk secara instan perlu dilatih secara serius dan proporsional agar membentuk karakter yang ideal.

Bentuk implementasi peduli sosial yang dapat dilaksanakan pada masyarakat pluralismedi Cigugur Kuningan adalah menyumbang dan melayat warga masyarakat yang meninggal. Menjenguk atau membantu warga masyarakat yang sakit, memberikan sumbangan untuk pembangunan atau perbaikan rumah ibadah, parit, dan jalan, ikut serta dalam gotong-royong membangun rumah warga masyarakat sebagai wujud kesetiakawanan, menjaga keamanan lingkungan, dan menolong warga masyarakat yang terkena musibah bencana alam seperti banjir, gempa bumi, longsor, kebakaran, dan lain-lain.

\section{PENUTUP}

Fenornena kerukunan antarumat beragama yang terjadi di Cigugur, Kuningan, Jawa Barat merupakan suasana nyata tentang kehidupan beragama yang saling menjaga, melengkapi, dan menghargai antara satu sama lain, yang membuat masyarakat Cigugur hidup dalam keharmonisan dan kedamaian di dalamnnya. Terciptanya kehidupan yang rukun dan damai bukanlah suatu kondisi yang tercipta dengan begitu saja tanpa ada yang mendasari kedua hal tersebut dapat terjadi. Tentu ada faktor-faktor yang melatarbelakangi kesuksesan pendidikan karakter peduli sosial warga Cigu- 
gur walau mereka hidup dengan lingkungan masyarakat yang memiliki keragaman agama. Faktor-faktor tersebut berupa tempat ibadah, organisasi sosial kemasyarakatan, pembiasaan dalam kegiatan-kegiatan masyarakat, dan keteladanan dari pemimpin, tokoh agama, serta tokoh masyarakat.

Pendekatan penanaman nilai karakter peduli sosial yang diterapkan di masyarakat Cigugur Kuningan yaitu metode keteladanan dan pembiasaan. Keteladanan muncul dari pemimpin, tokoh masyarakat, dan terutama dari para tokoh agama Islam, Katolik, dan ADS. Metode pembiasaan dilakukan melalui kegiatan gotong royong dalam membangun tempat ibadah, perbaikan rumah warga, serta pembuatan parit dan jalan; bakti sosial atau memberi sumbangan ketika ada bencana alam atau musibah.

\section{UCAPAN TERIMA KASIH}

Penulis mengucapkan syukur kepada Allah SWT. atas segala kemudahan dalam menjalani penelitian dan penulisan artikel ini.Penulisjuga berterima kasih kepada Sekretaris Desa Cisantana Cigugur Kuningan, Ari Rianto; Ketua BUMDES Cisantana Cigugur Kuningan, Agus Susanto; Imam Katolik Cigugur Kuningan, Rama Andreas Dedi, OSC; perwakilan dari agama Islam, H. Darsono; pemimpin Susteran Ursulin Desa Cisantana Cigugur Kuningan; Sr. Bernadeth, OSU; Guru PNS di SDN 2 Cisantana; Christina Nina; Kepala Sekolah PKBM Bumi Cahya, Sr. Yuliana, S.Sos; perwakilan dari ADS; dan bidan Puskesmas Cisantana, Ela Romlah.

\section{DAFTAR PUSTAKA}

Afandi, R. (2011). Integrasi pendidikan karakter dalam pembelajaran IPS di Sekolah Dasar. PEDAGOGIA: Jurnal Pendidikan, 1(1), 85-98. DOI: DOI: 10.21070/ pedagogia.v1i1.32.
Budiyono, A. (1983). Membina kerukunan hidup antar umat beriman (umat beragama dan penganut kepercayaan kepada Tuhan Yang Maha Esa). Surakarta: Pusat Pembinaan Katekin Vicep Surakarta.

Damayanti, D. (2014). Panduan implementasi pendidikan karakter di sekolah. Yogyakarta: Ariska.

Eryana, E. Y. (2014). Konstruksi pendidikan karakter peduli sosial perspektif PPKn (Analisis semiotik pada film Alangkah Lucunya (negeri ini). Skripsi. Surakarta: Universitas Muhammadiyah Surakarta. Diunduh dari: http://eprints.ums.ac.id/31010/15/NASKAH _PUBLIKASI.pdf.

Kahmad, D. (2009). Sosiologi agama. Bandung: Remaja Rosda Karya.

Kurniawan, M.I. (2015). Tri pusat pendidikan sebagai sarana pendidikan karakter anak Sekolah Dasar. PEDAGOGIA: Jurnal Pendidikan, 4(1), 41-49. DOI: 10.21070/pedagogia.v4i1.71.

Kurniawati, F.E. (2015). Pengembangan bahan ajar aqidah ahklak di Madrasah Ibtidaiyah. Jurnal Penelitian, 9(2), 367388. Diunduh dari: http://journal.stainkudus.ac.id/index.php/jurnalPe nelitian/article/viewFile/1326/1170.

Marzuki \& Haq, P.I. (2018). Penanaman nilai-nilai karakter religius dan karakter kebangsaan di Madrasah Tsanawiyah Al Falah Jatinangor Sumedang. Jurnal Pendidikan Karaker, 8(1), 84-94. DOI: 10.21831/jpk.v8i1.21677.

Megawangi, R. (2010, November 24). Pengembangan program pendidikan karakter di sekolah: pengalaman sekolah karakter. Diunduh dari Repository UT: http://repository.ut.ac.id/2486/1/fk 
ip201002.pdf. Diakses tanggal 10 Januari 2019.

Mustari, M. (2011). Nilai karakter: Refleksi untuk pendidikan karakter. Yogyakarta: Laksbang Pressindo.

Palunga, R. \& Marzuki. (2017). Peran guru dalam pengembangan karakter peserta didik di Sekolah Menengah Pertama Negeri 2 Depok Sleman. Jurnal Pendidikan Karaker, 7(1), 109-122. DOI: 10.21831/jpk.v7i1.20858.
Raharjo, S.B. (2010). Pendidikan karakter sebagai upaya menciptakan akhlak mulia. Jurnal Pendidikan dan Kebudayaan, 16(3), 229-238. DOI: $10.24832 \% 2 F j p-$ nk.v16i3.456.

Samani, M. \& Hariyanto. (2014). Konsep dan model pendidikan karakter. Bandung: Rosda Karya.

Suryana, T. (2011). Konsep dan aktualisasi kerukunan antar umat beragama. Jurnal Pendidikan Agama Islam-Ta'lim, 9(2), 127-136. Diunduh dari: https://www.scribd.com/doc/241284023/03 -Konsep-Dan-Aktualisasi-Kerukunan-Antar-Umat-Beragama-Toto. 